\title{
ROLE OF TRUST ON ORGANIZATIONAL CITIZENSHIP BEHAVIOR (OCB): PERSPECTIVE FROM THE EMPLOYEE ON THE RETAIL SECTOR IN BANDUNG, INDONESIA
}

\author{
Ester Manik \\ ${ }^{1}$ Sekolah Tinggi Ilmu Ekonomi, Pasundan, Bandung, Indonesia. \\ E-mail: ester@stiepas.ac.id
}

\begin{abstract}
Individual behavior that can increase organizational effectiveness is an essential aspect for organizations to achieve optimal performance. For this reason, there is a need for research that can contribute to improving individual behavior in producing its effectiveness. However, previous research has shown a theoretical gap in measuring individual trust and organizational citizenship behavior. In theory, to fill the gap, this study measures the influence of individual beliefs and organizational citizenship behavior. Researchers surveyed employees who work in the retail sector as many as 257 employees. The researchers used a structural equation modeling approach - PLS with predictive purposes to test the research model. The study results indicate that there is a positive influence on individual beliefs based on intention and individual beliefs on actions on organizational citizenship behavior. The study's implications indicate the need to increase the motivational aspect to increase individual confidence so that it will lead to behavioral actions that can increase organizational effectiveness.
\end{abstract}

Keywords: individual beliefs, individual behavior in organizations.

\section{INTRODUCTION}

Competition in the industrial sector is increasing increasingly complex due to consumer knowledge about the quality of the products/services they use. (Taghizadeh, Rahman \& Hossain, 2018) In addition to increasing consumer knowledge, technological advances also cause competition between companies to deepen where each company will carry out various strategies to retain its customers. (Akroush, 2012; Najafi-Tavani, NajafiTavani, Naudé, Oghazi \& Zeynaloo, 2018). This condition causes an increase in the need for quality resources owned by the organization. (Abubakar, Elrehail, Alatailat \& Elçi, 2019) One of the roles that can achieve the established strategy is increasing the capacity of human resources within the organization. (Suryadana \& Sidharta, 2019) 
One thing that management pays attention to in managing its human resources is to develop optimal behavior within the organization. (Allan, Batz-Barbarich, Sterling \& Tay, 2019) Behavior within this organization reflects in attitudes and actions reflected interactions between employees and between superiors and the community in their environment. (Zhang, Akhtar, Bal, Zhang \& Talat, 2018) This attitude reflects in the positive behavior shown by employees, such as helping each other in completing work and helping in solving problems in completing tasks set by the organization. (Organs, 2018) The behavior of employees expected by the organization is called organizational citizenship behavior (OCB). Organizational citizenship behavior is a measurement of individual behavior in an organization that expects by management in addition to assigned tasks such as task performance. (Katz, 1964; Organ, 1997)

The critical role of organizational citizenship behavior in the organizational environment is to increase organizational goals' effectiveness in achieving organizational performance. (Katz, 1964; Organ, 1997) Behavior that has not standard can increase organizational effectiveness is one of the essential aspects for the organization. This behavior is a response to the need to achieve more than the set performance due to the high level of competition. (Deery, Rayton, Walsh \& Kinnie, 2017) More roles are desired by organizations as indicated by their enthusiasm for work, assisting employees who need problem-solving, following rules, and supporting the organization desired by companies in increasing the effectiveness of organizational goals. (Szabó, Czibor, Restás \& Bereczkei, 2018) Aspects of organizational citizenship behavior play an essential role for individuals to perform behaviors that exceed their contractual performance and overlap with other aspects of job appraisal.

Some researchers emphasize aspects that are interrelated with organizational citizenship behavior while others emphasize different aspects; however, the results of the meta-analysis conducted by LePine, Erez, \& Johnson (2002) show no significant difference between these aspects.

The criticism of the measurement of organizational citizenship behavior carries by Williams \& Anderson (1991). Podsakoff, Whiting, Podsakoff \& Blume (2009), who offered the measurement of organizational citizenship behavior with the approach of individual and organizational aspects. They criticize the extent to which individual roles are measured, making it challenging to measure behavior, and there is ambiguity in its measurement. Individual discretionary behavior is challenging to measure, so it will be more accessible when viewed from individual and organizational aspects. (Motowildo, Borman \& Schmit, 1997) Podsakoff, Whiting, Podsakoff \& Blume (2009) show that organizational citizenship behavior from behavior that conveys between individuals and organizational citizenship behavior from behavior directed to organizations has a strong correlation. The results of this study indicate that both individual and organizational dimensions are part of the measurement of organizational citizenship behavior constructs.

There are several relationships between the constructs of organizational citizenship behavior and task performance (Miao, Humphrey \& Qian, 2018), psychological capital (Gupta, Shaheen \& Reddy, 2017), organizational trust (Yildiz, 2019), emotional intelligence (Miao, Humphrey \& Qian, 2017), job satisfaction (Spector \& Che, 2014), 
organizational commitment (Cetin, Gürbüz \& Sert, 2015), leadership (Nohe \& Hertel, 2017), motivational aspect (Singh \& Srivastava, 2009), stressors (Eatough, Chang, Miloslavic \& Johnson, 2011) absenteeism and turn over (Lee \& Allen, 2002).

One aspect related to organizational citizenship behavior is individual trust in the organization. Trust is one of the most important factors in the organization because it is closely related to individual behavior in behaving and acting. (Nohe \& Hertel 2017) To achieve organizational effectiveness, the organization needs to trust its employees to expect to act as expected by the organization. (Lee, Ahn \& Kim, 2018) However, there are still complex issues related to increasing individual trust in the organization. (Singh \& Srivastava, 2016) The complexity of individual beliefs within the organization causes individual factors and the organizational environment and the environment outside the organization that is still related to the organization. One of the complexities of the problem of employee trust is regarding the assessment made by the management of their performance (Carpenter, Berry \& Houston, 2014). Meyer \& Davis (1999) conducted experimental research showing the relationship between trust and performance appraisal in organizations. Further research conducted by Cook \& Wall (1980) showed the relationship between individual belief behavior with organizational commitment and personal need. The study results indicate that individual trust is a desire to take any action that results in other individuals and their environment as indicated by organizational commitment and fulfillment of personal needs.

Several measurements of individual trust within the organization refer to vertical and horizontal relationships related to relationships between individuals and superiors. This difference is the perspective of individuals and non-individuals who refer to personal ranking, reputation, and roles in groups within the organization (Adams \& Sartori, 2005). Several factors can influence trust, such as psychological aspects (Yildiz, 2019), human resources management practice (Liu, Huang, Huang \& Chen, 2013), leadership, personality, organizational justice, performance appraisal, and organizational culture. Likewise, the impact of trust that will increase work engagement (Schneider, Macey, Barbera \& Young, (2010), organizational commitment (Tekingündüz, Top, Tengilimoğlu \& Karabulut, 2017), job satisfaction (Gilstrap \& Collins, 2012), collaboration (Breuer, Hüffmeier \& Hertel, 2016), team (Nienaber, Romeike, Searle \& Schewe, 2015) and task performance (Rich, 1997).

Research conducted by Yildiz (2019) showed that there was a positive influence of organizational trust on organizational citizenship behavior and also showed a moderating role in psychological capital, measuring organizational citizenship behavior using the dimensions developed by Podsakoff (1990) referring to the Organ dimension (1988). The meta-analysis conducted by Nohe \& Hertel (2017) proves the influence of transformational leadership on organizational citizenship behavior and shows the mediation of relational trust. Singh \& Srivastava (2016) showed the effect of organizational trust on organizational citizenship behavior, measuring organizational citizenship behavior using the dimensions developed by Podsakoff \& Mackenzie (1989). Furthermore, Liu, Huang, Huang \& Chen (2013) proved the positive influence of organizational trust on organizational citizenship behavior. 
The theoretical gap of the research described previously is the purpose of this study. There are differences in approaches in measuring individual trust and organizational citizenship behavior; there is a need for research that can bridge the differences in previous research. The researcher hopes that this research can contribute to the development of empirical research on the measurement of organizational trust and organizational citizenship behavior within the organization's scope.

\section{METHOD}

This study uses a sample of employees who work in the retail sector in Bandung, Indonesia. A total of 257 employees who work in the retail sector contributed to this research. The employee's workplace is a mini-market that includes the retail sector, respondents who answer the questionnaire by filling out the instrument online using a google form that first given a link form that made previously. The collection of respondents' answers took place for 1 (one) month, mostly men by $54 \%$ while women $46 \%$, dominated by ages between 20 years -25 years as much as $37 \%$, while as many as $7 \%$ employees aged 35 years - 40 years.

After collecting the research instruments, the researcher recapitulated the results of the respondents' answers which then tested for the validity and reliability of the research instrument. The results of the research instrument testing show valid and reliable results by first excluding items that have values below the recommended ones.

The research instrument refers to the instrument developed by Cook \& Wall (1980) for measuring individual confidence, which consists of 12 (twelve) statement items divided into 2 (two) dimensions, namely the intention dimension and the action dimension with a reliability level of 0.85 . At the same time, the measurement of organizational citizenship behavior refers to Williams \& Anderson (1991), which consists of 16 (sixteen) statement items that measure individual aspects with a reliability level of 0.83 and organizational aspects with a reliability level of 0.88 .

To predict the proposed model, the researcher uses structural equation modeling PLS, an excellent tool to test the predictions of exploratory research models. The test results can see in the results section and further discussion.

\section{RESULTS AND DISCUSSION}

Instrumental testing to ensure that the instrument used was valid and reliable to test the research model's predictions. After that, the researcher conducted a factorial test for the individual confidence variable. The calculation results for testing the instrument refer to table 1 below. 
Table 1. Instrument validity and reliability

\begin{tabular}{|l|l|l|l|l|l|}
\hline Instruments & $\begin{array}{l}\text { Outer } \\
\text { Loading }\end{array}$ & Rho A & $\begin{array}{l}\text { Cronbach's } \\
\text { Alpha }\end{array}$ & AVE & $\begin{array}{l}\text { Composite } \\
\text { Reliability }\end{array}$ \\
\hline Trust & & & & & \\
\hline TR-I.1 & 0,800 & 0,906 & 0,887 & 0,642 & 0,914 \\
\hline TR-I.2 & 0,802 & & & & \\
\hline TR-I.3 & 0,854 & & & & \\
\hline TR-I.4 & 0,789 & & & & \\
\hline TR-I.5 & 0,649 & & & & \\
\hline TR-I.6 & 0,892 & & & & \\
\hline TR-A.1 & 0,858 & 0,908 & 0,830 & 0,592 & 0,876 \\
\hline TR-A.2 & 0,521 & & & & \\
\hline TR-A.3 & 0,759 & & & & \\
\hline TR-A.5 & 0,790 & & & & \\
\hline TR-A.6 & 0,866 & & & & \\
\hline OCB & & & & & \\
\hline OCB.1 & 0,684 & 0,875 & 0,857 & 0,500 & \\
\hline OCB.2 & 0,517 & & & & \\
\hline OCB.5 & 0,796 & & & & \\
\hline OCB.7 & 0,714 & & & & \\
\hline OCB.8 & 0,787 & & & & \\
\hline OCB.14 & 0,709 & & & & \\
\hline OCB.15 & 0,804 & & & & \\
\hline
\end{tabular}

Table 1 presents the results of the research instrument testing; it can see that several statement items do not meet the validity and reliability criteria; there is 1 (one) invalid statement item for the individual confidence variable. There are 8 (eight) statement items from the statement items of organizational citizenship behavior that are not valid. Overall the research variables are valid with a loading value level $>0.5$ and reliable with a rho_A value $>0.7$, Cronbach's Alpha value $>0.7$ and a Composite Reliability value $>0.7$ and an AVE value $>0.5$. Factor analysis testing tests the measurement of individual confidence whether the research instrument consists of 2 (two) dimensions as described previously.

Table 2. The results of the individual confidence variable factorial

\begin{tabular}{|l|c|}
\hline KMO Measure Adequacy. & .896 \\
Bartlett's Test Sig. & .000 \\
\hline Item & .639 \\
\hline TR.1 & .342 \\
\hline TR.2 & .721 \\
\hline TR.3 & .733 \\
\hline TR.4 & Communalities Extraction \\
\hline
\end{tabular}




\begin{tabular}{|c|c|c|}
\hline \multicolumn{2}{|l|}{ TR.5 } & .659 \\
\hline \multicolumn{2}{|l|}{ TR.6 } & .418 \\
\hline \multicolumn{2}{|l|}{ TR.7 } & .657 \\
\hline \multicolumn{2}{|l|}{ TR.8 } & .778 \\
\hline \multicolumn{2}{|l|}{ TR.9 } & .708 \\
\hline \multicolumn{2}{|l|}{ TR.11 } & .667 \\
\hline \multicolumn{2}{|l|}{ TR.12 } & .597 \\
\hline \multicolumn{3}{|c|}{ Total Variance Explained } \\
\hline \multicolumn{2}{|r|}{$\%$ of Variance } & Cumulative $\%$ \\
\hline 1 & 50.342 & 50.342 \\
\hline 2 & 9.400 & 59.742 \\
\hline
\end{tabular}

Table 2 shows the results of factor analysis testing where there are 2 (two) factors form individual beliefs; these two factors are the dimension of intention and the dimension of action with a KMO test value of 0.896 and a sig level of 0.000 for Bartlett's Test. The total variation that can explain is $59.74 \%$; this value indicates that the individual confidence variable can explain more than $50 \%$.

Table 3. Factorial Rotation Results

\begin{tabular}{|l|c|c|}
\hline & TR-I & TR-A \\
\hline TR-I.6 & .891 & \\
\hline TR-I.5 & .876 & \\
\hline TR-I.3 & .842 & \\
\hline TR-I.1 & .776 & \\
\hline TR-I.2 & .735 & \\
\hline TR-I.4 & .437 & .879 \\
\hline TR-A.3 & & .871 \\
\hline TR-A.2 & & .719 \\
\hline TR-A.5 & & .599 \\
\hline TR-A.1 & & .489 \\
\hline TR-A.6 & & \\
\hline
\end{tabular}

In factorial rotation, it can see that the statement instrument forms 2 (two) factors with a value of $0.437-0.891$ for the first factor and a value of $0.489-0879$ for the second factor.

Table 4. Results of research variable predictors

\begin{tabular}{|c|c|c|c|}
\hline Predictors & B & p-value & Result \\
\hline TR-I -> OCB & 0,742 & 0,000 & Significant \\
\hline TR-A -> OCB & 0,281 & 0,018 & Significant \\
\hline R2 & & & \\
\hline OCB & 0,336 & 0,000 & Significant \\
\hline
\end{tabular}


Table 4 presents information on the results of the prediction decisions of the research model carried out, where individual trust based on intention has a significant effect and trust based on action. Figure 1 can clarify the relationship between the research variables that have to carry out.

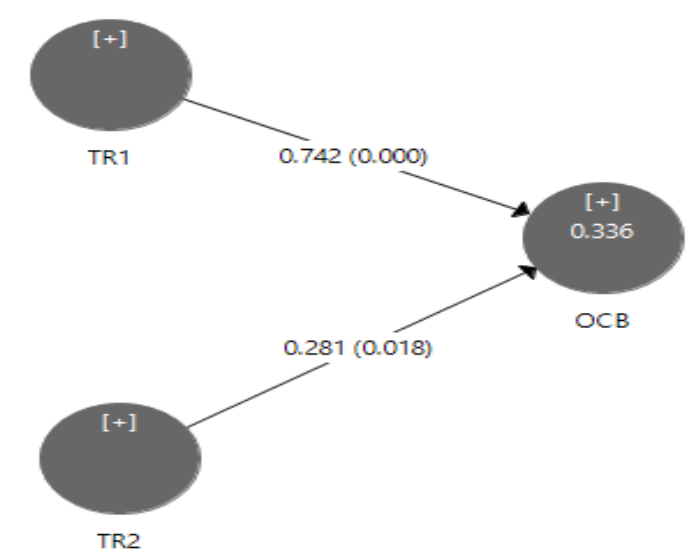

Figure 1. Predictor research variables

Table 4 and Figure 1 show that the research model tested has a significant effect. Individual trust based on intention to organizational citizenship behavior has a significant p-value of 0.000 with $b$ of 0.742 . In contrast, individual trust based on action on organizational citizenship behavior has a significant $p$-value of 0.18 with $b$ of 0.281 . At the same time, the value of $r$ square is 0.336 with a $p$-value of 0.000 . The prediction results indicate that individual trust in intensity can increase organizational citizenship behavior and individual trust in action. Therefore, increased organizational citizenship behavior of employees expects to increase organizational effectiveness following the organization's wishes.

Individual trust in intention is shown by the organization's efforts to fulfill employees' interests and improve their work attitude. With trust in the organization, employees will not hesitate in completing tasks. Individual trust is also shown by the help of colleagues when experiencing difficulties in solving problems. These conditions can encourage employees to be enthusiastic in completing their work even though there are obstacles in completing them. Likewise, management's reputation for being fair will encourage employees to trust management. With a positive perception of co-workers and the management in treating their employees, it will create conducive conditions in completing their work by helping colleagues if there are obstacles and always maintaining the image of the organization in the organizational environment. The behavior of these employees will have an impact on the effectiveness of employees in the organization. (Organs, 2018)

Individual trust based on actions indicates by employees' attitudes who believe that management has carried out excellent and beneficial policies for employees and trust between colleagues. This condition will lead to employee behavior which is indicated by the attitude of helping each other between employees, trusting each other, and treating coworkers politely and respectfully to superiors. With the employee's trust in the 
organization, it will create favorable conditions for employees, marked by the behavior of providing constructive ideas for the organization and maintaining the organization's image both within and outside the organization. In addition, employee behavior is also concern about the organization by participating in activities that can improve the organization's image.

Individual behavior that behaves outside of the tasks assigned to him and creates conditions conducive to the organization that will impact the organization's overall effectiveness. (Podsakoff, Podsakoff, MacKenzie, Maynes \& Spoelma, 2014) The behavior of these employees can encourage task effectiveness among employees and can create harmonious relationships both between employees and with superiors. The work situation is good for the organization, so it is necessary to strive so that the management can make comprehensive efforts to have positive perceptions that will increase their trust and improve organizational citizenship behavior. Efforts that can increase motivational aspects such as providing rewards for employees who have high organizational citizenship behavior can also carry out performance appraisal efforts objectively so that employee confidence can increase.

The results of this study support the research conducted by Yildiz (2019) by adding different measurements to the organizational citizenship behavior variable. Similarly, research conducted by Singh \& Srivastava (2016) with different measurements of organizational citizenship behavior can add to the predictions that can affect organizational effectiveness. As well as research by Yildirim (2014), individual trust in the measurement of organizational communication has an impact on organizational citizenship behavior.

\section{CONCLUSION}

The study results indicate that there is a positive influence on individual beliefs based on intent and individual beliefs based on actions on organizational citizenship behavior. Conducive conditions in the work environment marked by trust between employees and superiors can create work effectiveness. This employee behavior is a positive action desired by the organization to face the demands of increasingly high competition. Individual trust can also predict positive behavior, which indicates their loyalty to the organization by showing good performance. Individual behavior shows that they maintain the organization's image to give a good reputation both within the organization and outside the organization.

The study's implications indicate the need to increase motivational aspects such as rewards to increase individual confidence so that it will lead to behavioral actions that can increase organizational effectiveness. Thus, this research contributes to filling the theoretical gap as previously described. However, this study still has several weaknesses where the test is only at the level of prediction, not yet at the stage of explanatory testing. 
For further research, it is possible to develop model testing with an explanatory approach using a more comprehensive sample to generalize the results of the study.

\section{REFERENCES}

Abubakar, A. M., Elrehail, H., Alatailat, M. A., \& Elçi, A. (2019). Knowledge management, decision-making style and organizational performance. Journal of Innovation \& Knowledge, 4(2), 104-114. https://doi.org/10.1016/j.jik.2017.07.003

Adams, B. D., \& Sartori, J. A. (2005). The dimensionality of trust. HUMANSYSTEMS INC GUELPH (ONTARIO).

Akroush, M. N. (2012). Organizational capabilities and new product performance: The role of new product competitive advantage. Competitiveness Review: An International Business Journal, 22(4), 343-365. https://doi.org/10.1108/10595421211247178

Allan, B. A., Batz-Barbarich, C., Sterling, H. M., \& Tay, L. (2019). Outcomes of meaningful work: A meta-analysis. Journal of Management Studies, 56(3), 500-528. https://doi.org/10.1111/joms.12406

Breuer, C., Hüffmeier, J., \& Hertel, G. (2016). Does trust matter more in virtual teams? A meta-analysis of trust and team effectiveness considering virtuality and documentation as moderators. Journal of Applied Psychology, 101(8), 1151 -1177.

Carpenter, N. C., Berry, C. M., \& Houston, L. (2014). A meta-analytic comparison of self-reported and other-reported organizational citizenship behavior. Journal of Organizational Behavior, 35(4), 547-574. https://doi.org/10.1002/job.1909

Cetin, S., Gürbüz, S., \& Sert, M. (2015). A meta-analysis of the relationship between organizational commitment and organizational citizenship behavior: Test of potential moderator variables. Employee responsibilities and rights journal, 27(4), 281-303. https://doi.org/10.1007/s10672-015-9266-5

Cook, J., \& Wall, T. (1980). New work attitude measures of trust, organizational commitment and personal need non-fulfilment. Journal of occupational psychology, 53(1), 39-52.

Deery, S., Rayton, B., Walsh, J., \& Kinnie, N. (2017). The costs of exhibiting organizational citizenship behavior. Human Resource Management, 56(6), 1039-1049. https://doi.org/10.1002/hrm.21815

Eatough, E. M., Chang, C. H., Miloslavic, S. A., \& Johnson, R. E. (2011). Relationships of role stressors with organizational citizenship behavior: a meta-analysis. Journal of Applied Psychology, 96(3), 619-632. https://doi.org/10.1037/a0021887

Gupta, M., Shaheen, M., \& Reddy, P. K. (2017). Impact of psychological capital on organizational citizenship behavior: Mediation by work engagement. Journal of 
Management Development, 36(7), 973-983. https://doi.org/10.1108/JMD-06-20160084

Gilstrap, J. B., \& Collins, B. J. (2012). The importance of being trustworthy: Trust as a mediator of the relationship between leader behaviors and employee job satisfaction. Journal of Leadership \& Organizational Studies, 19(2), 152-163. https://doi.org/10.1177/1548051811431827

Katz, D. (1964). The motivational basis of organizational behavior. Behavioral science, 9(2), 131-146. https://doi.org/10.1002/bs.3830090206

Lee, Y. J., Ahn, J. S., \& Kim, M. J. (2018). The relationship between organizational justice, organizational trust, and organizational citizenship behavior of hospital office workers, focusing on the moderating effect of hospital scales. The Korean Journal of Health Service Management, 12(1),

13-22. https://doi.org/10.12811/kshsm.2018.12.1.013

Lee, K., \& Allen, N. J. (2002). Organizational citizenship behavior and workplace deviance: The role of affect and cognitions. Journal of applied psychology, 87(1), 131142 .

LePine, J. A., Erez, A., \& Johnson, D. E. (2002). The nature and dimensionality of organizational citizenship behavior: a critical review and meta-analysis. Journal of applied psychology, 87(1), 52-65.

Liu, C. M., Huang, C. J., Huang, K. P., \& Chen, K. J. (2013). Psychological contract breach, organizational trust and organizational citizenship behavior of hotel industry in Taiwan. Pakistan Journal of Statistics, 29(5), 635-648.

Mayer, R. C., \& Davis, J. H. (1999). The effect of the performance appraisal system on trust for management: A field quasi-experiment. Journal of applied psychology, 84(1), 123-136.

Miao, C., Humphrey, R. H., \& Qian, S. (2017). Are the emotionally intelligent good citizens or counterproductive? A meta-analysis of emotional intelligence and its relationships with organizational citizenship behavior and counterproductive work behavior. Personality and Individual Differences, 116, 144-156. https://doi.org/10.1016/j.paid.2017.04.015

Miao, C., Humphrey, R. H., \& Qian, S. (2018). A cross-cultural meta-analysis of how leader emotional intelligence influences subordinate task performance and organizational citizenship behavior. Journal of World Business, 53(4), 463-474. https://doi.org/10.1016/j.jwb.2018.01.003

Motowildo, S. J., Borman, W. C., \& Schmit, M. J. (1997). A theory of individual differences in task and contextual performance. Human performance, 10(2), 71-83.

Najafi-Tavani, S., Najafi-Tavani, Z., Naudé, P., Oghazi, P., \& Zeynaloo, E. (2018). How collaborative innovation networks affect new product performance: Product innovation capability, process innovation capability, and absorptive 
capacity. Industrial marketing management, 73,

193-205. https://doi.org/10.1016/j.indmarman.2018.02.009

Nienaber, A. M., Romeike, P. D., Searle, R., \& Schewe, G. (2015). A qualitative metaanalysis of trust in supervisor-subordinate relationships. Journal of Managerial Psychology, 30(5), 507-534. https://doi.org/10.1108/JMP-06-2013-0187

Nohe, C., \& Hertel, G. (2017). Transformational leadership and organizational citizenship behavior: A meta-analytic test of underlying mechanisms. Frontiers in Psychology, 8, 1364. https://doi.org/10.3389/fpsyg.2017.01364

Organ, D. W. (1997). Organizational citizenship behavior: It's construct clean-up time. Human performance, 10(2), 85-97. https://doi.org/10.1207/s15327043hup1002_2

Organ, D. W. (2018). Organizational citizenship behavior: Recent trends and developments. Annual Review of Organizational Psychology and Organizational Behavior, 80, 295-306.

Podsakoff, N. P., Whiting, S. W., Podsakoff, P. M., \& Blume, B. D. (2009). Individualand organizational-level consequences of organizational citizenship behaviors: A meta-analysis. Journal of applied Psychology,94(1), 122-141. https://doi.org/10.1037/a0013079

Podsakoff, N. P., Podsakoff, P. M., MacKenzie, S. B., Maynes, T. D., \& Spoelma, T. M. (2014). Consequences of unit-level organizational citizenship behaviors: A review and recommendations for future research. Journal of Organizational Behavior, 35(S1), S87-S119. https://doi.org/10.1002/job.1911

Rich, G. A. (1997). The sales manager as a role model: Effects on trust, job satisfaction, and performance of salespeople. Journal of the Academy of Marketing Science, 25(4), 319-328. https://doi.org/10.1177/0092070397254004

Schneider, B., Macey, W. H., Barbera, K. M., \& Young, S. A. (2010). The role of employee trust in understanding employee engagement. In Handbook of employee engagement. Edward Elgar DOI:https://doi.org/10.4337/9781849806374.00020

Singh, U., \& Srivastava, K. B. (2009). Interpersonal trust and organizational citizenship behavior. Psychological Studies, 54(1), 65-76. https://doi.org/10.1007/s12646-0090008-3

Singh, U., \& Srivastava, K. B. (2016). Organizational trust and organizational citizenship behaviour. Global Business Review, 17(3), 594-609. https://doi.org/10.1177/0972150916630804

Spector, P. E., \& Che, X. X. (2014). Re-examining citizenship: How the control of measurement artifacts affects observed relationships of organizational citizenship behavior and organizational variables. Human Performance, 27(2), 165-182. https://doi.org/10.1080/08959285.2014.882928 
Szabó, Z. P., Czibor, A., Restás, P., \& Bereczkei, T. (2018). “The Darkest of all” The relationship between the Dark Triad traits and organizational citizenship behavior. Personality and Individual Differences, 134, 352-356. https://doi.org/10.1016/j.paid.2018.04.026

Suryadana, M. L., \& Sidharta, I. (2019). Manajemen sumber daya manusia industri hospitality: Diandra Kreatif. Yogyakarta: Diandra Kreatif.

Taghizadeh, S. K., Rahman, S. A., \& Hossain, M. M. (2018). Knowledge from customer, for customer or about customer: which triggers innovation capability the most?. Journal of Knowledge Management, 22(1), 162-182. https://doi.org/10.1108/JKM-12-2016-0548

Tekingündüz, S., Top, M., Tengilimoğlu, D., \& Karabulut, E. (2017). Effect of organisational trust, job satisfaction, individual variables on the organisational commitment in healthcare services. Total Quality Management \& Business Excellence, 28(5-6), 522-541. https://doi.org/10.1080/14783363.2015.1099428

Yildirim, O. (2014). The impact of organizational communication on organizational citizenship behavior: research findings. Procedia-Social and Behavioral Sciences, 150, 1095-1100. https://doi.org/10.1016/j.sbspro.2014.09.124

Yildiz, H. (2019). The interactive effect of positive psychological capital and organizational trust on organizational citizenship behavior. SAGE Open, 9(3)1-15. DOI: $10.1177 / 2158244019862661$

Williams, L. J., \& Anderson, S. E. (1991). Job satisfaction and organizational commitment as predictors of organizational citizenship and in-role behaviors. Journal of management, 17(3), 601-617. https://doi.org/10.1177/014920639101700305

Zhang, J., Akhtar, M. N., Bal, P. M., Zhang, Y., \& Talat, U. (2018). How do highperformance work systems affect individual outcomes: a multilevel $\begin{array}{lll}\text { perspective. Frontiers in } & \text { psychology, } 9, & \end{array}$ https://doi.org/10.3389/fpsyg.2018.00586 